\section{Green-up of Seeded Bermudagrass Cultivars as Influenced by Spring Scalping}

\author{
Filippo Rimi ${ }^{1}$, Stefano Macolino ${ }^{1,3}$, Bernd Leinauer ${ }^{2}$, \\ and Umberto Ziliotto ${ }^{1}$
}

AdDitional INDEX wORDs. Cynodon dactylon, warm-season turfgrasses, transition zone, green cover, spring green-up, turf management

SuMMARY. Winter dormancy is the main impediment to a wide acceptance of warmseason turfgrasses in the Mediterranean countries of Europe due to a loss of color during the winter months. Scalping during late winter or early spring has been recommended anecdotally to enhance spring green-up of bermudagrass (Cynodon dactylon); however, information is lacking on the effectiveness of this practice. A study was conducted to investigate the effects of spring scalping on spring green-up of eight bermudagrass cultivars (Barbados, Contessa, La Paloma, Mohawk, NuMex Sahara, Princess-77, SR 9554, and Yukon) grown in a transition zone environment. The trial was carried out in Spring of 2009 and 2010 on plots established in July 2005 at the experimental farm of the University of Padova (northeastern Italy). Half of the plots for each cultivar were subjected to spring scalping, which was applied in both years on $13 \mathrm{Mar}$. with a rotary mower set at a height of $28 \mathrm{~mm}$. Soil temperatures were recorded hourly during the research period at a depth of $2.5 \mathrm{~cm}$. The percentage of green cover was estimated weekly from 0 to 98 days after spring scalping (DASS). Soil temperatures in scalped plots were greater than in unscalped plots. Among the cultivars tested, 'Yukon' showed earliest spring green-up, with no difference between the scalping treatments, reaching $80 \%$ green cover by the end of April. For all other cultivars, scalped plots reached $80 \%$ green cover 10 to 18 days earlier than unscalped plots. Results showed that scalping enhanced spring greenup, primarily for cultivars that recover slowly from winter dormancy.

I $\mathrm{n}$ the transition zones of the Mediterranean Europe, including most of Italy, turfs are mostly composed of cool-season species. Maintaining cool-season grasses in these areas has been questioned because of their high irrigation requirements relative to warm-season species. Cool-season turfgrasses use more water than warmseason grasses due to their higher evapotranspiration rates during the summer months and longer growing period. Evapotranspiration rates for warm-season grasses range from 2 to $5 \mathrm{~mm} \cdot \mathrm{d}^{-1}$ compared with 3 to $8 \mathrm{~mm} \cdot \mathrm{d}^{-1}$ for cool-season grasses (Casnoff et al., 1989; Huang, 2008). Although warmseason turfgrasses are best adapted to

This research was supported by the Italian Ministry of Instruction, University and Research.

We gratefully acknowledge Rossana Sallenave and Giampaolo Zanin for their help in reviewing the manuscript. Appreciation is extended to the three anonymous reviewers, the consulting editor, and the associate editor for their constructive comments.

${ }^{1}$ Department of Environmental Agronomy and Crop Production, University of Padova, viale dell'Università 16, Agripolis 35020, Legnaro, Padova, Italy

${ }^{2}$ Department of Extension Plant Sciences, New Mexico State University, N230 Skeen Hall, Las Cruces, NM 88003

${ }^{3}$ Corresponding author. E-mail: stefano.macolino@ unipd.it. warm climates, they can be successfully grown in transitional environments (de Bruijn, 2010; Volterrani et al., 2004). To reduce water consumption for landscape irrigation, their use could be encouraged in Mediterranean countries of Europe.

Winter dormancy and poor tolerance to low temperatures represent the main impediments to warm-season grasses gaining greater acceptance in the Mediterranean countries. In transition zones, warm-season grasses lose color in autumn and are susceptible to low temperature injury during the cooler months (Beard, 1973; Munshaw et al., 2006; Richardson, 2002). In some transition zone regions, the warmseason turfgrasses remain dormant for up to 5 months, which strongly inhibits their widespread use. However, low temperature tolerance and spring green-up can be improved through appropriate cultivar selection and the application of proper management practices (Anderson et al., 2007; Patton et al., 2008).

Bermudagrass, currently, is the warm-season turf species most widely used in the European countries because of its recuperative potential, wear tolerance, and pest resistance (Beard, 1973; Croce et al., 2003). In transition zones, bermudagrass may be used in pure stands or overseeded in the fall with cool-season grasses, such as perennial ryegrass (Lolium perenne) or annual ryegrass (Lolium multiflorium) to provide year-round green color (Goddard et al., 2008; Schmidt and Shoulders, 1980).

The spring green-up of bermudagrass in the transition zone has been an important issue for many years. Bermudagrass spring recovery usually begins when the soil temperature reaches $10{ }^{\circ} \mathrm{C}$ and the active growing period continues until the soil temperature decreases below this level in the fall (Youngner, 1959). Several studies have reported on the role of carbohydrates in turfgrass spring shoot renewing (Macolino et al., 2010; Rogers et al., 1975; Trenholm et al., 1998). Nonstructural carbohydrates are accumulated in storage organs (stolons and rhizomes) of turfgrasses in autumn during cold acclimatation and used in spring as an energy source to support the spring green-up (Stier and Fei, 2008). The speed to recovery after winter dormancy has been considered a main factor in selecting bermudagrass cultivars for the transition zones (Patton et al., 2008; Richardson et al., 2004). Spring green-up has been studied with emphasis on fertilization (Goatley et al., 1994; Miller and Dickens, 1996a, 1996b; Trenholm et al., 1998) and other management practices, such as winter turf covers (Goatley et al., 2005) and plant growth regulators (Richardson, 2002; White and Schmidt,

\begin{tabular}{llll}
\hline $\begin{array}{l}\text { Units } \\
\begin{array}{l}\text { To convert U.S. to SI, } \\
\text { multiply by }\end{array}\end{array}$ & U.S. unit & SI unit & $\begin{array}{l}\text { To convert SI to U.S., } \\
\text { multiply by }\end{array}$ \\
\hline 0.3048 & $\mathrm{ft}$ & $\mathrm{m}$ & 3.2808 \\
2.54 & inch(es) & $\mathrm{cm}$ & 0.3937 \\
25.4 & inch(es) & $\mathrm{mm}$ & 0.0394 \\
0.0418 & langley(s) & $\mathrm{MJ} \cdot \mathrm{m}^{-2}$ & 23.9006 \\
1.1209 & lb/acre & $\mathrm{kg} \cdot \mathrm{ha}^{-1}$ & 0.8922 \\
1 & $\mathrm{ppm}$ & $\mathrm{mg} \cdot \mathrm{kg}^{-1}$ & 1 \\
$\left({ }^{\circ} \mathrm{F}-32\right) \div 1.8$ & ${ }^{\circ} \mathrm{F}$ & ${ }^{\circ} \mathrm{C}$ & $\left(1.8 \times{ }^{\circ} \mathrm{C}\right)+32$
\end{tabular}


1989). Collectively, these studies demonstrated that great potential exists for accelerating the spring green-up of bermudagrass through the application of appropriate cultural practices and cultivar selection.

During the growing season, removing more than $40 \%$ of the turf height in a single mowing can cause scalping, resulting in unattractive part of the plants (Beard, 1973). However, the deliberate application of scalping in early spring removes dead leaf tissue and allows sunlight to reach the new growth next to the ground and can allow for earlier spring green-up (Brede, 2000; Christians, 1998). Depractice, no studies have been published on the effectiveness of spring scalping in promoting green recovery. To address this knowledge gap, the influence of spring scalping on spring green-up of eight bermudagrass cultivars was studied for 2 years in a transition zone environment.

\section{Materials and methods}

A field trial was conducted from Mar. 2009 to June 2010 at the experimental agricultural farm of Padova University in Legnaro, northeastern Italy (lat. $45^{\circ} 20^{\prime} \mathrm{N}$, long. $11^{\circ} 57^{\prime} \mathrm{E}$, elevation $8 \mathrm{~m}$ ), to investigate the effect of spring scalping on eight seeded bermudagrass cultivars. The area has a humid subtropical climate and is similar to plant hardiness zone 8 (U.S. Department of Agriculture, 1990) with a rainfall of $820 \mathrm{~mm}$ distributed patches and exposure of the lower spite the suggested use of this cultural

throughout the year (Table 1$)$. The soil at the site was a coarse-silty, mixed, mesic, Oxyaquic Eutrudept (Morari, 2006), containing 20\% clay, $61 \%$ silt, and $19 \%$ sand, with a $\mathrm{pH}$ of $8.3,2.1 \%$ organic matter, a carbon: nitrogen ratio of 11.4 , an available phosphorus content of $30 \mathrm{mg} \cdot \mathrm{kg}^{-1}$, and an exchangeable potassium content of $147 \mathrm{mg} \cdot \mathrm{kg}^{-1}$. The experiment was carried out on mature turf plots that were established in 2005. Bermudagrass cultivars included Barbados, Contessa, La Paloma, Mohawk, NuMex Sahara, Princess-77, SR 9554, and Yukon.

During the growing periods of the 3 years before the onset of the study (2005-08) a slow-release fertilizer $(20 \mathrm{~N}-2.2 \mathrm{P}-6.6 \mathrm{~K})$ was applied in May, June, July, August, and September at a rate of $40 \mathrm{~kg} \cdot \mathrm{ha}^{-1}$ of nitrogen. In addition, plots were mowed weekly at an effective height of cut of 52 mm using a rotary mower (HRD 536; Honda Europe Power Equipment, Ormes, France) with an effective mowing width of $55 \mathrm{~cm}$ and clippings were removed. The mowing height was chosen because it is the height at which bermudagrass in low maintenance (zero irrigation) areas in Italy is typically maintained.

In 2009 and 2010, spring scalping was applied on 13 Mar. with a rotary mower set at a height of $28 \mathrm{~mm}$ (effective height of cut). Regular weekly mowing started 28 DASS. No additional irrigation to natural precipitation was provided during the study, and plots were fertilized in May, June, and

Table 1. Monthly average air temperature and precipitation from 2009 to 2010 and long-term (1963-2007) mo.ly meteorological averages for the research location at the experimental farm of Padova University, Legnaro, northeastern Italy.

\begin{tabular}{lccccccc}
\hline & \multicolumn{3}{c}{ Air temp $\left({ }^{\circ} \mathbf{C}\right)^{\mathbf{z}}$} & & \multicolumn{3}{c}{ Precipitation $(\mathbf{m m})^{\mathbf{z}}$} \\
\cline { 2 - 4 } \cline { 7 - 8 } Month & $\mathbf{2 0 0 9}$ & $\mathbf{2 0 1 0}$ & $\mathbf{4 5 - y r} \mathbf{~ a v g}$ & & $\mathbf{2 0 0 9}$ & $\mathbf{2 0 1 0}$ & $\mathbf{4 5 - y r}$ avg \\
\hline January & 2.9 & 2.5 & 2 & & 57 & 59 & 53 \\
February & 5.2 & 4.9 & 4.1 & & 57 & 127 & 49 \\
March & 9 & 8.1 & 7.8 & & 104 & 38 & 56 \\
April & 14.3 & 13.7 & 11.6 & & 126 & 45 & 69 \\
May & 20.2 & 17.7 & 16.6 & & 26 & 110 & 74 \\
June & 21.6 & 21.9 & 20.2 & & 87 & 111 & 82 \\
July & 24.2 & 24.7 & 22.3 & & 79 & 96 & 74 \\
August & 25.3 & 22.4 & 21.9 & & 21 & 91 & 76 \\
September & 20.8 & 17.9 & 18.2 & & 190 & 112 & 72 \\
October & 14.3 & 12.7 & 13.1 & & 44 & 87 & 80 \\
November & 10.7 & 9.8 & 7.2 & & 92 & 153 & 76 \\
December & 3.8 & 2.6 & 2.9 & & 113 & 112 & 60 \\
Annual & 14.4 & 13.3 & 12.3 & & 996 & 1141 & 820 \\
\hline
\end{tabular}

${ }^{\mathrm{z}}\left(1.8 \times{ }^{\circ} \mathrm{C}\right)+32={ }^{\circ} \mathrm{F}, 1 \mathrm{~mm}=0.0394$ inch.
August with ammonium nitrate at 66 $\mathrm{kg} \cdot \mathrm{ha}^{-1}$. The experimental design was a completely randomized split block with bermudagrass cultivars as the main plot and scalping as the subplot treatment. Main plots and subplots were replicated four times and measured $1.6 \times 4.5 \mathrm{~m}$ and $1.6 \times 2.3 \mathrm{~m}$, respectively.

Green cover for each subplot was visually estimated weekly beginning immediately after the scalping treatment until 98 DASS. A sigmoidal model (GraphPad Prism 5.0 for Windows; GraphPad Software, La Jolla, CA) was used to calculate DASS required to reach $80 \%$ of green color for each plot (Macolino et al., 2010). Eight temperature sensors (thermocouples) were installed at a soil depth of $2.5 \mathrm{~cm}$ in four randomly selected scalped subplots and in the corresponding unscalped subplots. Thermocouples were connected to a data logger (CRI0X; Campbell Scientific, Logan, UT), and soil temperature was recorded hourly throughout the research period. Daily maximum soil temperature difference (DMTD) was calculated by subtracting the recorded minimum temperature from the maximum temperature for each day during the investigative period. Air temperature and incident solar radiation were measured by a weather station (WTS 7000; MTX Italia, Modena, Italy) located in close proximity to the research plots (Fig. 1). The DMTDs were then regressed against daily incident solar radiation and daily air temperature. The linear regression was calculated for the time period of 13 Mar. (day when scalping treatments were applied) to 3 May (day when plots reached an average of $80 \%$ green cover).

The effects of scalping, cultivar, and year on DASS to reach $80 \%$ of green cover were statistically analyzed using a repeated measures analysis of variance (ANOVA) with SAS Proc Mixed (version 9.2; SAS Institute, Cary, NC). A compound symmetry covariance structure resulted in the best fit for the data (lowest Akaike information criterion value). Tukey's honestly significant difference test was used at the $P$ level of 0.05 to identify significant differences among means.

\section{Results and discussion}

The ANOVA revealed significant three-way interactions among cultivars, scalping, and years $(P=0.015)$. The two-way interactions between 
cultivars and scalping $(P=0.003)$ and between cultivars and years $(P=$ $0.004)$, and all the main effects $(P<$ $0.001)$ were also significant. The twoway interactions between scalping and years was not significant $(P=0.853)$.

With the exception of 'Yukon', spring green-up was enhanced by scalping for all the cultivars in both years of the study (Fig. 2; Table 2). For 'Barbados', 'Contessa', 'La Paloma', 'Mohawk', 'NuMex Sahara', 'Princess77', and 'SR 9554', scalping reduced the time required to reach $80 \%$ green cover by 8 to $18 \mathrm{~d}$ compared with unscalped plots in 2009 and by 8 to $16 \mathrm{~d}$ in 2010 (Table 2). When subjected to spring scalping, 'La Paloma' did not differ from 'Yukon' in both 2009 and 2010 (Table 2). 'Yukon' exhibited the shortest time to reach $80 \%$ green cover in unscalped plots in both years (Fig. 2; Table 2). Macolino et al. (2010) studied the concentration of water soluble carbohydrates in stolons of the same bermudagrass cultivars involved in this research and reported that 'Yukon' exhibited the highest concentration in March. Based on these previous findings and the results of this study, it appears that spring scalping could be less effective for cultivars that are rich in water soluble carbohydrates in late winter.

In 2009, the green-up period (March to May) was warmer than in 2010, whereas the solar radiation was greater in 2010 than in 2009 (Fig. 1). With respect to scalping, differences in air temperature and solar radiation between the two experimental years may have subjected the test cultivars to different environmental conditions, which may have influenced the effects of scalping, and may explain the significant cultivar $\times$ scalping $\times$ year interaction. Averaged over the 2 years, 'Yukon' was the only cultivar that differed from the others in scalped plots, showing the earliest spring green-up, whereas differences occurred among the other cultivars in unscalped plots (Table 2). When data were averaged over the eight cultivars and the 2 years, spring scalping enhanced time to reach $80 \%$ green cover by an average of 11 $\mathrm{d}$ (Table 2), confirming the hypothesis that scalping in early spring is helpful to accelerate green-up.

Differences in spring green-up among cultivars were consistent across the 2 years of study although there was

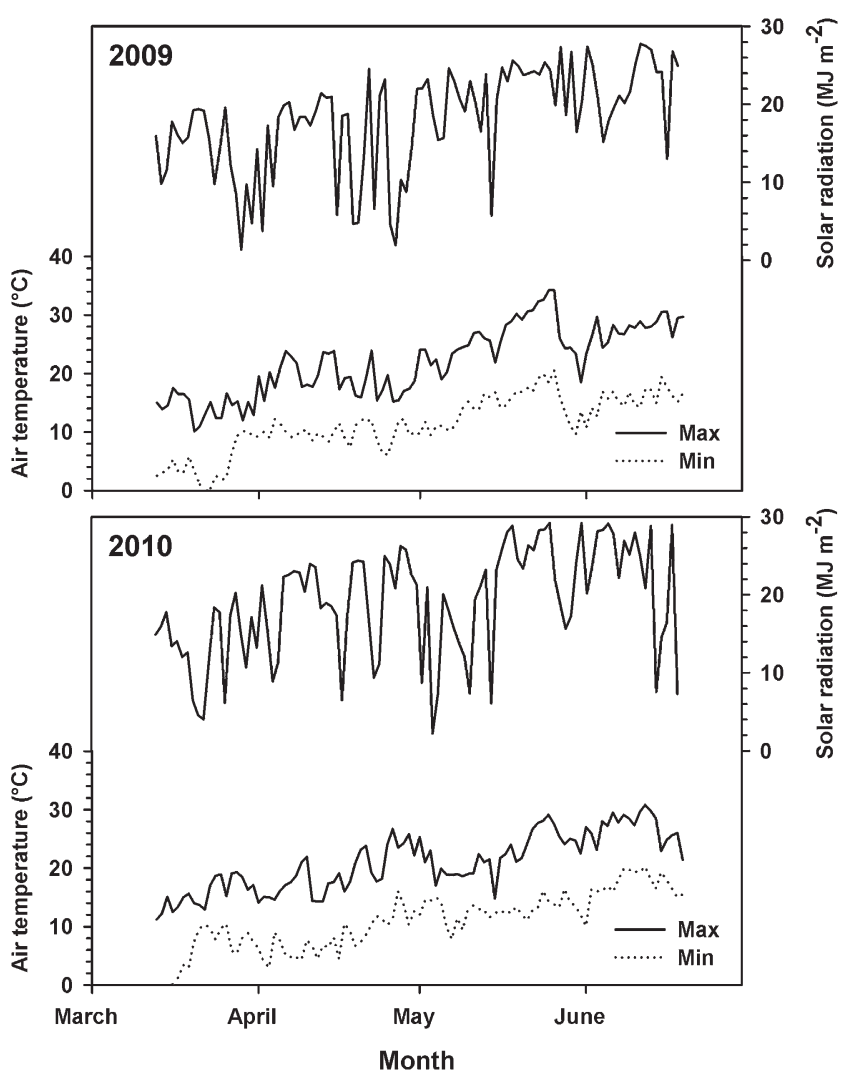

Fig. 1. Maximum (Max) and minimum (Min) air temperature and incident solar radiation from 13 Mar. [0 d after spring scalping (DASS)] to 19 June (98 DASS) during 2009 and 2010 at the experimental farm of Padova University, Legnaro, Italy; $\left(1.8 \times{ }^{\circ} \mathrm{C}\right)+32={ }^{\circ} \mathrm{F}, 1 \mathrm{MJ} \cdot \mathrm{m}^{-2}=23.9006$ langleys.
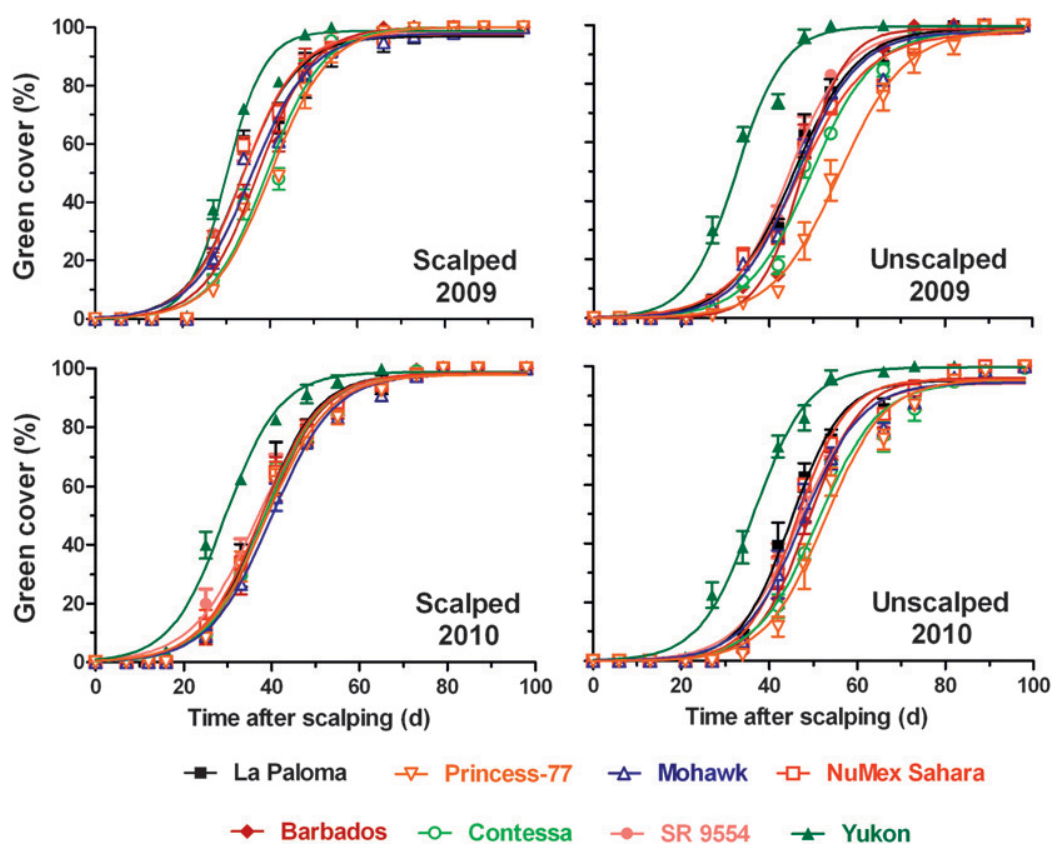

Fig. 2. Percent green cover as a function of number of days after spring scalping for eight scalped and unscalped bermudagrass cultivars (La Paloma, Princess-77, Mohawk, NuMex Sahara, Barbados, Contessa, SR 9554, and Yukon) in 2009 and 2010. Data points represent an average of four replicates and bars indicate $\pm \mathrm{SE}$. 
Table 2. Mean number of days required to reach $\mathbf{8 0 \%}$ of green cover (estimates based on sigmoidal model) for eight scalped and unscalped bermudagrass cultivars in 2009 and 2010. Days were counted on both scalped and unscalped plots beginning on the day scalping treatments were applied. Data were replicated four times and were collected in Legnaro, northeastern Italy.

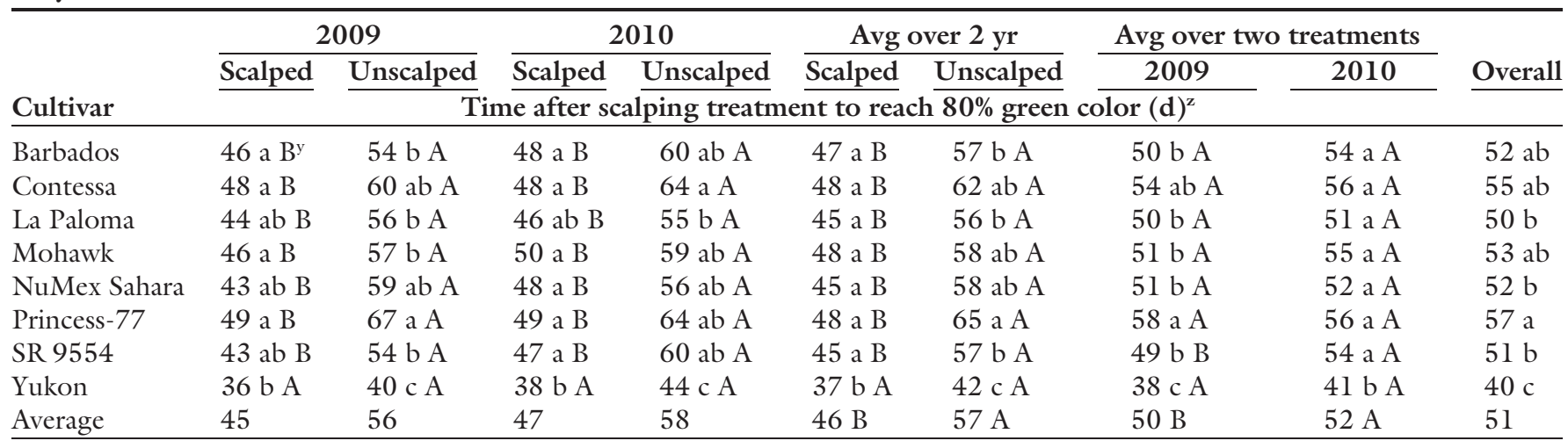

${ }^{z}$ Spring scalping applied on 13 Mar. 2009 and 13 Mar. 2010.

yalues followed by the same letter are not significantly different from one another at the $5 \%$ level of significance according to the Tukey's honestly significant difference test. Lower case letters denote differences between cultivars (in columns), upper case letters denote differences between treatments and between years for each cultivar separately.

a difference in magnitude that resulted in a cultivar $\times$ year interaction (Table 2 ). 'Yukon' showed earliest spring green-up and reached $80 \%$ green cover by the end of April in both 2009 and 2010 (38 DASS and 41 DASS, respectively) (Table 2). In 2009, 'Barbados', 'La Paloma', 'Mohawk', 'NuMex Sahara', and 'SR 9554' reached 80\% green cover 11-13 d later than 'Yukon', whereas 'Contessa' and 'Princess-77' were $15 \mathrm{~d}$ and $19 \mathrm{~d}$, respectively, later than 'Yukon' (Table 2). In the subsequent year, 'Barbados', 'Contessa', 'La Paloma', 'Mohawk', 'NuMex Sahara', 'Princess-77', and 'SR 9554' needed 11-15 d longer than 'Yukon' to reach $80 \%$ green cover, without significant differences among the cultivars (Table 2). Time necessary to reach $80 \%$ green cover was on average $2 \mathrm{~d}$ longer in 2010 , under cooler early spring conditions, than in 2009 (Table 2). This result, together with the nonsignificant scalping $\times$ year interaction, suggests that the effectiveness of scalping may not be greatly influenced by air temperature conditions in early spring.

Scalping applications affected soil temperatures in both experimental years. From immediately after scalping application until the end of April, maximum soil temperatures were higher in scalped plots than in unscalped in both years, whereas minimum temperatures were unaffected (Fig. 3). A strong positive relationship was found between DMTD and solar radiation during the period of spring green-up for scalped and unscalped plots (Fig. 4).

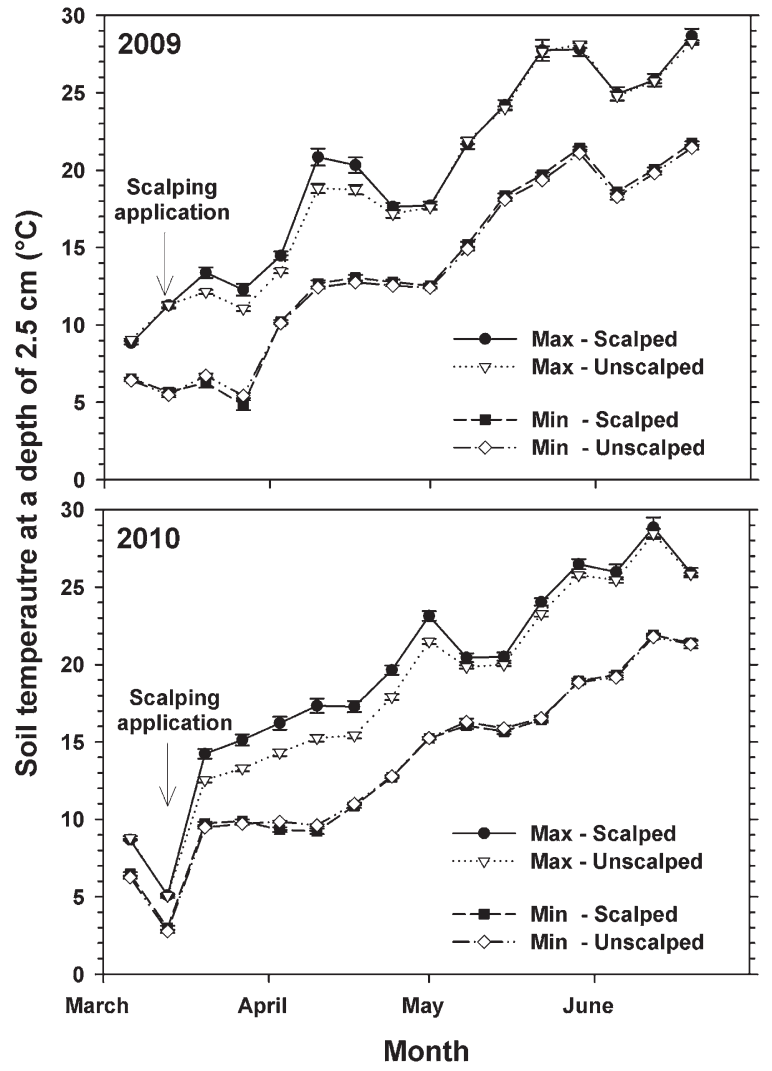

Fig. 3. Weekly average maximum (Max) and minimum (Min) soil temperatures at a depth of $2.5 \mathrm{~cm}(0.98 \mathrm{inch})$ in scalped and unscalped bermudagrass plots in 2009 and 2010 . Data points represent an average of four replicates and bars indicate $\pm \mathrm{SE}$; $\left(1.8 \times{ }^{\circ} \mathrm{C}\right)+32={ }^{\circ} \mathrm{F}$.

The two treatments had significantly different slopes, showing a higher increment of DMTD as solar radiation increases for scalped than unscalped plots. Maximum air temperatures showed a weaker relationship with DMTD in both scalped $\left(r^{2}=0.24\right.$;
$P<0.001)$ and unscalped plots $\left(r^{2}=\right.$ $0.33 ; P<0.001)$ and no differences between the two fitted regressions (data not shown). These results suggest that scalping increases light penetration through the turf canopy, resulting in increased maximum soil 


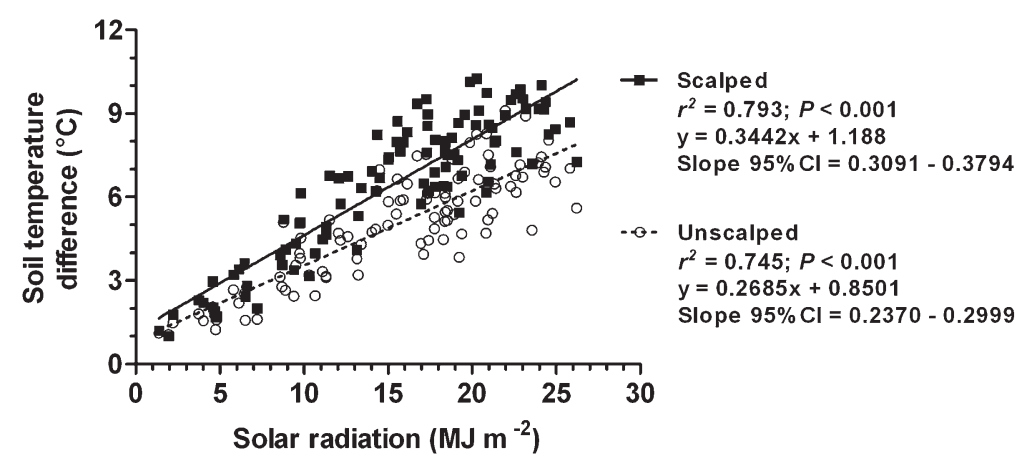

Fig. 4. Relationship between daily soil temperature differences (maximum minimum temperature $)$ at $2.5 \mathrm{~cm}(0.98 \mathrm{inch})$ depths and incident solar radiation for scalped and unscalped bermudagrass plots. Data are the average of four replicates and were collected over the period beginning on the day scalping was applied until plots reached $80 \%$ of green cover across 2 years (13 Mar. 2009 to 1 May 2009, 13 Mar. 2010 to 3 May 2010); CI, confidence interval; $1 \mathrm{MJ} \cdot \mathrm{m}^{-2}=23.9006$ langleys, $\left(1.8 \times{ }^{\circ} \mathrm{C}\right)+32={ }^{\circ} \mathrm{F}$.

temperatures during the spring greenup period. The strong influence of light penetration on scalping effectiveness could also explain the lack of a significant scalping $\times$ year interaction. The greater solar radiations in 2010 may have increased the effectiveness of the scalping treatment, which would have compensated for the lower air temperatures (Fig. 1).

When data were averaged over the scalping treatments and the 2 years, 'Yukon' was the earliest to achieve green-up, reaching $80 \%$ green cover by the end of April (40 DASS), whereas 'Princess-77' showed the slowest green-up (Table 2). These results corroborated the findings of Macolino et al. (2010), in which 'Yukon' had the earliest spring greenup after establishment, whereas 'Princess-77' was in the slowest group. Similar results have been published by the National Turfgrass Evaluation Program's 2007 bermudagrass trial (National Turfgrass Evaluation Program, 2010), reporting that 'Yukon' showed a significantly faster green-up than 'Princess-77' in three locations across the United States.

In summary, the results of this study demonstrated that the application of spring scalping enhances greenup of bermudagrass by increasing the soil temperatures during the day. However, the effectiveness of this practice was influenced by varietal response. Among the cultivars tested, 'Yukon' showed the earliest spring green-up, regardless of the scalping treatment applied. Spring scalping is highly recommended for bermudagrass cultivars that are slow to green-up in the spring.

\section{Literature cited}

Anderson, J.A., C.M. Taliaferro, and Y.Q. Wu. 2007. Freeze tolerance of seed- and vegetatively propagated bermudagrasses compared with standard cultivars. Appl. Turfgrass Sci. doi: 10.1094/ATS-20070508-01-RS

Beard, J.B. 1973. Turfgrass: Science and culture. Prentice Hall, Upper Saddle River, NJ.

Brede, D. 2000. Turfgrass maintenance reduction handbook: Sports, lawns, and golf. Sleeping Bear Press, Chelsea, MI.

Casnoff, D.M., R.L. Green, and J.B. Beard. 1989. Leaf blade stomatal densities of ten warm-season perennial grasses and their evapotranspiration rates. Proc. VI Intl. Turfgrass Res. Conf., 129-131.

Christians, N.C. 1998. Fundamental of turfgrass management. Ann Arbor Press, Chelsea, MI.

Croce, P., A. De Luca, M. Mocioni, M. Volterrani, and J.B. Beard. 2003. Adaptability of warm season turfgrass species and cultivars in a Mediterranean climate. Acta Hort. 661:365-368.

de Bruijn, K. 2010. Warm-season grasses for the Mediterranean area. Proc. II European Turfgrass Soc. Conf., Angers, France, 11-14 Apr. 2010, 245-249.

Goatley, J.M., Jr, V. Maddox, D.J. Lang, and K.K. Crouse. 1994. 'Tifgreen' bermudagrass response to late-season application of nitrogen and potassium. Agron. J. 86:7-10.

Goatley, J.M., Jr, V.L. Maddox, D.L. Lang, R.E. Elmore, and B.R. Stewart. 2005. Temporary covers maintain fall bermudagrass quality, enhance spring greenup, and increase stem carbohydrate levels. HortScience 40:227-231.
Goddard, M.J.R., J.C. Sorochan, J.S. McElroy, D.E. Karcher, and J.W. Landreth. 2008. The effects of crumb rubber topdressing on hybrid kentucky bluegrass and bermudagrass athletic fields in the transition zone. Crop Sci. 48:2003-2009.

Huang, B. 2008. Turfgrass water requirements and factors affecting water usage, $p$. 193-205. In: J.B. Beard and M.P. Kenna (eds.). Water quality and quantity issues for turfgrass in urban landscapes. Council Agr. Sci. Technol. Spec. Publ. No. 27.

Macolino, S., M. Serena, B. Leinauer, and U. Ziliotto. 2010. Preliminary findings on the correlation between water-soluble carbohydrate content in stolons and first year green-up of seeded bermudagrass cultivars. HortTechnology 20:758-763.

Miller, G.L. and R. Dickens. 1996a. Bermudagrass carbohydrate level as influenced by potassium fertilization and cultivar. Crop Sci. 36:1283-1289.

Miller, G.L. and R. Dickens. 1996b. Potassium fertilization related to cold resistance in bermudagrass. Crop Sci. 36:1290-1295.

Morari, F. 2006. Drainage flux measurement and errors associated with automatic tension-controlled suction plates. Soil Sci. Soc. Amer. J. 70:1860-1871.

Munshaw, G.C., E.H. Ervin, C. Shang, S.D. Askew, X. Zhang, and R.W. Lemus. 2006. Influence of late-season iron, nitrogen, and seaweed extract on fall color retention and cold tolerance of four bermudagrass cultivars. Crop Sci. 46:273-283.

National Turfgrass Evaluation Program. 2010. 2007 National Bermudagrass Test: 2009 Data. 15 Oct. 2010. <http:/ /www.ntep. org/data/bg07/bg07_10-4/bg0710t10a. txt>.

Patton, A.J., M.D. Richardson, D.E. Richter, J.W. Boyd, Z.J. Reicher, J.D. Fry, J.S. McEroy, and G.C. Munshaw. 2008. A guide to establishing seeded bermudagrass in the transition zone. Appl. Turfgrass Sci. doi: 10.1094/ATS20080122-01-MD

Richardson, M.D. 2002. Turf quality and freezing tolerance of 'Tifway' bermudagrass as affected by late-season nitrogen and trinexapac-ethyl. Crop Sci. 42:16211626.

Richardson, M.D., D.E. Karcher, P. Berger, and J.W. Boyd. 2004. Utilizing improved seeded bermudagrasses on transition-zone sports fields. Acta Hort. 661: 369-374.

Rogers, R.A., J.H. Dunn, and C.J. Nelson. 1975. Cold hardening and carbohydrates composition of 'Meyer' zoysia. Agron. J. 67:836-838. 
Schmidt, R.E. and J.F. Shoulders. 1980. Seasonal performance of selected temperate turfgrasses overseeded on bermudagrass turf for winter sports. Proc. III Intl. Turfgrass Res. Conf., 75-86.

Stier, J.C. and S.Z. Fei. 2008. Cold stress physiology and management of turfgrasses, p. 473-505. In: M. Pessarakli (ed.). Handbook of turfgrass management and physiology. CRC Press, Boca Raton, FL.
Trenholm, L.E., A.E. Dudeck, J.B. Sartain, and J.L. Cisar. 1998. Bermudagrass growth, total nonstructural carbohydrate concentration, and quality as influenced by nitrogen and potassium. Crop Sci. 38:168-174.

U.S. Department of Agriculture. 1990. Plant hardiness zone map. U.S. Dept. Agr., Agr. Res. Serv. Misc. Publ. No. 1475.

Volterrani, M., M. Gaetani, S. Magni, and S. Miele. 2004. Bermudagrass autumn overseeding with annual ryegrass. Acta Hort. 661:353-356.

White, R.H. and R.E. Schmidt. 1989. Bermudagrass response to chilling temperatures as influenced by iron and benzyladenine. Crop Sci. 29:768-773.

Youngner, V.B. 1959. Growth of U-3 bermudagrass under various day and night temperatures and light intensities. Agron. J. 51:557-559. 